\title{
Reflections on the challenging mission of the country brand construct in the international business setting
}

\author{
Fabiana Gondim Mariutti ${ }^{1}$ \\ Leeds Beckett University - LBU, Leeds, England, UK
}

\section{ARTICLE DETAILS}

\section{Article history:}

Received 5 June de 2014

Accepted 19 March 2015

Available online 19 December 2015

Double Blind Review System

Scientific Editor

Felipe Mendes Borini

\section{Keywords:}

Country brand

Nation brand

Nation branding strategies

International business

\begin{abstract}
The importance of a strategically promoted country brand is a key goal in international business. Each nation tries to convey its attributes internationally, not only its products and services, but also its overall image. In addition, research on the country brand construct is continuous within academic environments, government offices, and corporate settings. Nations need to promote themselves strategically if they wish to ensure they are noticeable. Based on this premise, the aim of this theoretical reflection is to discuss this construct in to order to trace the development of the field and propose a conceptual framework for future research. This paper also contributes to understanding the challenging mission of the country brand construct and its strategies, both in practice and theory of the field. Moreover, it adds to current knowledge on the complexities of the country brand construct by understanding the topic's key philosophies after tracing its evolution. The combination of findings provides support for conveying a conceptual framework on the main complexities of the country brand construct, which are the following: multifaceted construct; numerous stakeholder-related; government involvement; interdisciplinary and multidisciplinary opportunities, and potential nation brand models. The present study advocates that dynamic nation branding strategies bring authenticity to countries in the international business setting and in doing so, this challenging mission of the country brand benefits international economy and trade; develops diplomatic relations; advances international marketing research; enhances academic and educational exchange programs and; improves both national and global sustainability.
\end{abstract}

(C) 2015 Internext | ESPM. All rights reserved!

\section{Introduction}

In the global economy arena, a country's image has become a key issue for competition and export growth. Consequently, it is becoming increasingly difficult to ignore the fact that developing countries are exposing themselves, whether purposely or not. Every brand identity reflects an image in the target market through different forms of communication and marketing activities (AAKER, 1992; KOTLER and KELLER, 2012) or brand experience (KAPFERER, 2004; SHIMP, 2007). Similarly, a nation brand echoes its image abroad or before a target-country using nation branding strategies or not, by simply performing its role worldwide, economically.

Invariably, people feel that their own identity is linked to their country's image (CEVERO, 2013) and every country creates an image in the mind of its people (ANHOLT, 2007; BIGNAMI, 2002; KOTLER and KELLER, 2012). A nation's identity deliberately redirects its multifaceted image, regardless of any theories and/or investigations. This study supports the brand as a conveyor of information for economic impact; moreover, the content of the information varies according to the audience the brand is addressing (LINDEMANN, 2010), since "countries, as well as individuals, can be brands" (LINDEMANN, 2010, p.7). However, Anholt (2000) and Sevin (2011) believe that the place itself needs to change in order to transform its own perception.

Theoretical studies on place branding have emerged rapidly over the last thirty years and gained gradual prominence (PAPADOPOULOS, 2004; MOILANEN and 
RAINISTO, 2009; DINNIE, 2009, 2016; KAVARATZIZ, 2010; GERTNER, 2011; WARNABY and MEDWAY, 2013). Place branding was an "unexplored" field until 2010 (HILDRETH, 2010), but has since advanced. According to Lucarelli and Brorström, the term place branding refers to "a mature and genuine research domain" (2013, p.66). Emphatically, anywhere can be defined as a place when marketed or promoted as such, including a country, city, region, university, school, house, building, airport, highway, street, park, stadium, circus, beach, mountain, etc. Furthermore, places reflect their own image, whether on purpose, planned, controlled or not. Based on this eclectic and broad range of options, the place selected for investigation in this study is the country.

Both 'nation brand and branding' and 'country brand and branding' will be discussed as conceptually synonymous terms in this study, using primarily 'nation' as a standard term, although it is understood they encompass specific theories and precise purposes. Fetscherin (2010, p.467) endorses that nation or country branding, "are used interchangeably in the literature". The reasons for this, which will be explained later in this literature, are grounded on previous studies.

However, a number of researchers address nation branding more as political, economic and diplomatic applications than simply marketing strategies (ARONCZYK, 2013; ROJAS-MÉNDEZ, 2013; ANHOLT, 2007; JANSEN, 2008; JAFFE and NEBENZAHL, 2001). As Anholt (2007) points out, the promotion of a country requires the government's complete involvement, particularly with respect to international relations and public diplomacy. Similarly, Jansen $(2008$, p.121) states that, for this type of promotion, "nation branding" is a more appropriate term than "country-branding" when it is "an applied communication practice that is supported by public policy and funding, and encouraged by international development and trade organizations including the United Nations, World Bank, World Trade Organization and others". Based on these conceptions, it seems that countries and nations are considered place brands, and therefore, specific nation brands. Nevertheless, according to Lucarelli and Brorström, place branding is "a mature and genuine research domain" (2013, p.66), while Braun $(2011$, p.40) feels that place branding is still in "its infancy in the academic field". Having established that a country is a place, place branding studies are taken into account in this paper, for which the researchers share this same theory (RUZZIER and DE CHERNATONY, 2013; DINNIE, 2013, 2005; GERTNER, 2011; GO and GOVERS, 2011; SEVIN, 2011; ASHWORTH and KAVARATZIZ, 2010; MAHESHWARI, 2010; MOILANEN and RAINISTO, 2009; KAVARATZIZ, 2005; RAINISTO, 2004).

Essentially, most scholars believe that country brand subjects are closely interconnected with place branding or marketing strategies (DINNIE, 2013; WARNABY and MEDWAY, 2013; ZAKAREVIČIUS and LONIKAITĖ, 2013; MOILANEN and RAINISTO, 2009; JANSEN, 2008; KAVARATZIZ, 2005; KOTLER and GERTNER, 2004; KOTLER, HAIDER and REIN, 1993). In addition, many activities, such as marketing and communication planning, are constantly combined with country brand strategies (GERTNER, 2011; KOTLER and KELLER, 2012; DINNIE, 2005; 2016). Kotler and Keller $(2012$, p.265) point out that marketing involves communicating value and building strong brands, evident in examples of places or nations.

Chan and Marafa (2013, p.237) highlight that place branding, as an area of research, "can incorporate a number of key concepts, including place identity, place image as projected by place marketers, place image and the value perceived by place users or consumers, user experience in the place, marketing and communications channels, and stakeholder relationships". Anholt (2007) and Kavaratziz (2005) and share this same view. From a similar and complementary perspective, these country branding strategies or tools signify place brand management, which "is as dynamic as its research domain", as emphasized by Chan and Marafa (2013, p.241).

Comparably, destination branding as a field is concerned with destination marketing in terms of the development of tourism brands (MORGAN, PRITCHARD and PRIDE, 2010; PIKE, 2008). Hall (2010) agrees that many studies on destination image have been conducted to identify attributes associated with specific places. More specifically, the number of tourism industry professionals and research specialists is rising rapidly (PHARR, 2005; BENI, 2006; PIKE, 2008; ASHWORTH and KAVARATZIS, 2010; MOILANEN and RAINISTO, 2009). However, this paper will focus on nation brand theories.

Place branding and nation branding are not new subjects in academia and acceptance of these concepts has grown considerably over the last 
decade, (ASHWORTH and KAVARATZIS, 2010; CEVERO, 2013; FETSCHERIN, 2010; SZONDI, 2007), in both academic and corporate environments (DINNIE, 2013, 2009; KOTLER and KELLER, 2012; ASHWORTH and KAVARATZIS, 2010; GERTNER; 2011; GO and GOVER, 2011; WARNABY and MEDWAY, 2013).

Indeed, government offices play a relevant role in maintaining and advertising a nation brand or its dimensions, with the latter continuously promoted with or without private sector participation. Several stakeholders instantly perceive the overall image of a nation the products' brand when they are internationally promoted or broadcasted. Additionally, one of the most significant current discussions on nation image is how international business, marketing, and communications professionals can use a nation's brand as a differential tool to develop that country, when successfully planned, applied and investigated. The main purposes of nation branding strategies in terms of their role in the international business setting and the respective authors' ideologies are diverse and limitless, including promoting tourism, supporting exports and attracting inward investment (KOTLER ET AL, 1993; JAFFE and NEBENZAHL, 2001; KOTLER and GERTNER, 2004; ANHOLT, 2000, 2007; DINNIE, 2008, 2013; MOILANEN and RAINISTO, 2009; FETSCHERIN, 2010; RUZZIER and DE CHERNATONY, 2013, KOTLER AND KELLER, 2012). It also maintains countries' sustainable development (JAFFE and NEBENZAHL, 2001; FETSCHERIN, 2010); stimulates immigration (ANHOLT, 2000, 2007; FETSCHERIN, 2010; KOTLER and KELLER, 2012); promotes public diplomacy and diplomatic relations (KOTLER et al. 1993; ANHOLT, 2000, 2007; JANSEN, 2008; MOILANEN and RAINISTO, 2009) and strengthens citizens' identity and self-esteem (RUZZIER and DE CHERNATONY, 2013; MOILANEN and RAINISTO, 2009).

Considering the above objectives, it is clear that any dimension of nation image has the potential to influence the overall spectrum of the nation branding strategy proposal. For instance, if a nation branding strategy specifically supports exports, it may also promote better public diplomacy relations between countries. Furthermore, progress in a country's tourism industry will certainly also benefit its sustainable development. A final important example is that if a positive nation branding strategy increases immigration, it will also raise inward investment, and vice versa. Effectively, the main objectives outlined above are complementary and categorize our research topics, linking them to the many dimensions of the nation brand construct.

\section{Aim of this Theoretical Paper}

The aim of this theoretical reflection is to discuss the nation brand construct in to order to trace the development of the field and propose conceptual frameworks for future research. As such, this conceptual paper reviews the nation brand construct and its origin and evolution since 1990. Previous studies have identified both similarities and differences among authors' viewpoints of nation branding; they tend to agree that it is important to focus on a country's promotion, but often have different reasons or perspectives for doing so. Debate continues in academic circles regarding the best approach or philosophy for managing a country's image. Thus, nation brand has been the subject of attention in international business and marketing, as well as public diplomacy. Undoubtedly, the roots of nation branding were founded in several indispensable and integrated disciplines, which have built this multidimensional construct. Finally, this paper reflects on the expansion of the nation branding concept in order to strategically support the nation's promotion abroad, whether intentionally planned or not.

\section{Literature Review}

Reflecting on international business is a vital practice in academic circles, which demands critical thinking and expertise. As stated by Zeng, Go and Kolmer (2011, p.319), "A country's position in terms of global competition can be influenced by its national image", associated with different international elements of a country. Therefore, the following two sections present the two main subtopics, namely the origin and evolution of nation branding, and the nation brand construct.

\section{Origin and Evolution of Nation Branding}

This section first addresses the origin and evolution of nation branding by investigating the existing definitions of nation branding, and their relation to other themes within academia, often associated with terms such as place branding, place marketing, place promotion, place brand management and integrated place marketing strategies. Lastly, this section 
presents the central goals of nation branding, and moves on to describe the main philosophies.

In recent last decades, a considerable amount of literature has been published on 'branding a nation' by both the academic and corporate sectors. However, the two leading research origins are 'country of origin' and 'nation as a brand'. Both theory-underpinning themes will be discussed in the following paragraphs. However, the present study will consider place branding as aligned to nation branding theories and philosophies, originating mostly from applied marketing and communications.

Although differences of opinion still exist, there is some consensus that nation branding refers to branding a country and its substantial and complex structure as a brand. Branding is central to understanding the practice and management of the nation brand construct. However, it is important to note the variety of integrated and linked definitions among the multifaceted and interdisciplinary constructs of place branding, place marketing and nation branding, suggested in previous studies. These are multifaceted academic theories whose meanings and application intersect with the field of business. Use of these terms often varies according to researchers' preferred definitions and those regarding the specific field. Although place branding has attracted interest from professionals in a number of academic disciplines, both academic and corporate articles on nation branding and place branding have increased over the last two decades (ASHWORTH and KAVARATZIS, 2010).

In fact, the first specific periodicals date from the last fifteen years. Considering terminology distinction, conceptual meaning and academic interest, established journals in the field are the Journal of Brand Management, created in 2002 with a special edition on "Country as a Brand"; Place Branding and Public Diplomacy, started in 2004 and the first journal dedicated exclusively to the field and, the Journal of Place Management and Development in 2008. Later, the Journal of Town and City Management and Place Branding emerged, although it is no longer published. The topic is addressed in more than forty journals (GERTNER, 2011), but place brand studies are typically published in the following: Journal of Product and Brand Management, Journal of Business Research, European Journal of Marketing, Tourism Planning and Development, Journal of Travel and Tourism Marketing, Journal of Vacation
Marketing, Journal of Travel Research, Journal of Euromarketing, Journal of Macromarketing, Journal of Marketing Management and Globalizacion, Competitividad and Governabilidad.

However, in the last fifty years, research has sought to identify the country of origin effect to determine the impact of a country's image on international perceptions of its products and services. Specifically, from an international marketing perspective, the "country of origin effect" was recommended by Kotler and Keller (2012, 2006), Usunier (2006), Kotler and Gertner (2004) and Kotler et al. (1993). According to Sethi and Elango (1999), country of origin effect is defined according to three elements, namely: (1) economic-physical resources, (2) cultural values and institutional rules and (3) economic and industry policies of the government.

Recently, Kotler and Keller (2012, p.639) stated that countries are marketed in the same way as any brand, declaring brand image as "the perceptions and beliefs held by consumers, as reflected in associations in consumer memory" and country of origin perceptions as "the mental associations and beliefs triggered by a country" (KOTLER AND KELLER, 2012, P.636).

Recently, Harengel and Gbadamosi (2014, p.36) reported that the country of origin theory is only part of the overall decision-making scenario, since it "is most often attributed in one direction, meaning the impact of the country for a specific set of brands." Dinnie (2009) also connects nation branding evolution to both the national identity and country of origin concepts due to the globalization phenomenon and competitiveness on the world stage. On the other hand, the author believes that the evolution of nation branding management also involves "product branding and service branding, followed by corporate branding" (DINNIE, 2009, p.22).

The first books to be published on the field, by Philip Kotler, were: Marketing Places Attracting Investment, Industry and Tourism to Cities, States and Nations (1993), The Marketing of Nations (1997), Marketing Place sin Europe (1999), Marketing Asian Places (2002) and Marketing for Hospitality and Tourism (2005). In addition, Papadopoulos and Heslop (1993) have studied product-country image from an international marketing perspective, whereby product image results from people's 
Table 1

Place Brand Philosophies

\begin{tabular}{|c|c|c|}
\hline Theory & Concept & Authors \\
\hline Places as Products & $\begin{array}{l}\text { Principals of branding applied to places and traditional } \\
\text { marketing theory can be transferred to a place context. }\end{array}$ & $\begin{array}{l}\text { Kotler et al.(1993); Ashworth (1994); } \\
\text { Ashworth and Kavaratzis (2010) } \\
\text { Warnaby and Medway (2013) }\end{array}$ \\
\hline $\begin{array}{l}\text { Place of Origin } \\
\text { Branding }\end{array}$ & $\begin{array}{l}\text { From a marketing perspective theory, linked to the place of } \\
\text { origin when branding a product. }\end{array}$ & $\begin{array}{l}\text { Kotler and Gertner (2004); } \\
\text { Papadopoulos and Heslop (2002) }\end{array}$ \\
\hline Nation branding & $\begin{array}{l}\text { From a marketing perspective, according to marketing } \\
\text { consultants as advisors of national governments and academic } \\
\text { researchers; primarily concerns government welfare and public } \\
\text { diplomacy. }\end{array}$ & $\begin{array}{l}\text { Anholt (2000, 2007); Papadopoulos } \\
\text { (2004); Dinnie (2005, 2009; 2016) }\end{array}$ \\
\hline Destination branding & $\begin{array}{l}\text { From a marketing perspective, used in tourism research; } \\
\text { involves the branding of tourism destinations. }\end{array}$ & Morgan et al. (2010) \\
\hline $\begin{array}{l}\text { Integrated } \\
\text { Place Branding }\end{array}$ & $\begin{array}{l}\text { From a marketing perspective, as per academic researchers. } \\
\text { Served as the basis for the field of place branding. Use of } \\
\text { communications and marketing channels and tools. }\end{array}$ & $\begin{array}{l}\text { Rainisto (2004); Papadopoulos (2004); } \\
\text { Kavaratzis (2005, 2010); Ashworth } \\
\text { and Kavaratzis (2010) }\end{array}$ \\
\hline
\end{tabular}

Source: Summarized from Moilanen and Rainisto (2009, p.5), Ashworth and Kavaratzis (2010, pp.4-6) and Dinnie (2009).

perceptions. Later, Papadopoulus (2004) focuses on place branding studies, evolution, meaning and implications.

From another standpoint, a large volume of published studies describe the role of places as products with particular dimensions (KOTLER et al., 1993; ASHWORTH, 1994; KAVARATZIS, 2005; PIKE, 2008; MOILANEN and RAINISTO, 2009; ASHWORTH and KAVARATZIS, 2010; FETSCHERIN, 2010; DINNIE, 2013; RUZZIER and DE CHERNATONY, 2013; LUCARELLI and BRORSTRÖM, 2013; WARNABY and MEDWAY, 2013). Likewise, a recent review of place branding methodologies by Chan and Marafa (2013) pointed to the evolution of the place branding concept, differentiating it from product marketing and corporate branding. At the same time, Bellini, Loffredo and Pasquinelli (2010, p.90) stated that "Place branding has been defined as the practice of applying brand strategy and other marketing techniques and disciplines to the economic, social, political and cultural development of cities, regions and countries".

Additionally, Rainisto (2004) was one of the first researchers on place marketing to focus on integrated place branding strategies. Later, Moilanen and Rainisto (2009) relied on the view that place marketing/branding is founded on place selling and business management. Kavaratziz (2005) also believes that the application of marketing efforts was initially developed from place promotion, then place marketing and, consequently, place branding, based on two distinct trends: place marketing theory and city administrator origins. From a destination branding standpoint, Pike (2008) reports that national stereotypes can permeate brand perception. However, Lamm and Molne (2013, p.10) disagree: "A nation brand cannot be promoted and advertised in the same way as a tourist destination".

By contrast, Hanna and Rowley (2009, p.103) agree: "A level of consensus on the definition of place branding or place brand management is central to the development of theoretical concepts and frameworks in the field, as well as benchmarking and promotion of good practice". The authors conducted a study on place brand management, where fifteen place brand practitioners across fifteen geographical locations and in several different destination management organisations, were asked to elaborate on what they understood by 'place brand management'. The findings confirm its multi-faceted definition, which focuses on "place identity, experience of the place, stakeholder engagement, and the place brand practitioner's leadership role in positioning and promoting the place proposition and experience". As previously explained, whether in a nation or any other place, "place branding brings added attraction to a place, the central issue being to build its brand identity" (RAINISTO, 2004, p.44).

With respect to delimiting the areas of activity on nation branding strategies, Dinnie (2016, p.243) reports that the nation brand's overall plan requires "internal and external analysis in order to access the current competitive position" According to Zeinalpour, Shahbazi and Ezzatirad (2013, p.317), "Country branding taps and is affected by economic, social, political, and communicational dimensions. A 
country brand can be a generic label or an omnipresent packaging, or may become a link between the political, social, and economic pillars of a nation. When properly designed and created, a brand can build a country and concentrate the tourism offer, which can stimulate investment within and outside a country, restore its reputation, and create renewed pride among its citizens."

In a complementary view, Haigh (BRAND FINANCE, 2013) state that, "Nations can adopt similar techniques to capitalize on the economic growth that comes with proper positioning of a nation brand. All nations should be working to actively realize this potential". These similar techniques are related to marketing and communications tools in order to strategically position the brand in the target market. In the case of a nation brand, there are many dimensions and variables involved in the specific purpose, need, or improvement of the target nation, or even globally.

These significant considerations lead to the main theories, which are shown in Table 1, followed by conceptual terminology.

The above table shows the evolution of solid and constant knowledge on nation brand-building since 1990. Collectively, these philosophies highlight the need for further research on nation branding to advance and cultivate new discoveries through communications and marketing efforts, as well as more specific activities.

In regard to other communications activities, Zeinalpour et al. (2013, p.321) recap "We also see new and innovative ways in which countries are promoting themselves: using global sports to showcase a nation, devising strong and groundbreaking environmental policies and approaches, electing powerful leaders who inspire global goodwill, and creating icons of culture and the arts."

According to Bellini et al. (2010, p.90), "Place branding has attempted to transfer into local economic development not only communications techniques, but also identity-building power", focused precisely on nation branding complexity. "For better or for worse, branding effects are pervasive," states Kotler and Keller (2012, p.264). Branding is the central strategic tool used to promote a place, whatever the main objective. Braun (2011, p.39) writes that cities use branding "to attract the attention of their desired target audiences", and so do countries.

According to Dinnie (2009, p.23), "countries as culturally and geographically diverse as Germany, South Korea, New Zealand, Scotland, Egypt, Britain and Spain have judged it worthwhile to develop nation branding strategies".

In closing this section, it is important to note that Ashworth and Voogd (1994, p.39, quoted in BELLINI et al, 2010, p.90) persuasively outlined that marketing has provided "a philosophy of place management".

\section{Nation Brand Construct}

Originally, Kotler and Levy (1969; cited in HARENGEL and GBADAMOSI, 2014, p.36) identified "branding of a nation as a potential area of research", proposing exploring marketing tools separately from "traditional business contexts". Over twenty years later, the field has expanded and been enriched as a result of new studies. For instance, Kotler et al. (1993) and Kotler and Gertner (2004) applied the concept of branding specifically to places in a similar manner as it is applied to products, services and companies, focusing primarily on marketing strategies to promote a place (nation). Almost twenty years later, Kotler and Keller (2012, p.265) point out that "Branding is endowing products and services with the power of a brand. For branding strategies to be successful and brand value to be created, consumers must be convinced there are meaningful differences among brands in the product or service category. Brand differences often relate to attributes or benefits of the product itself." Additionally, Kotler and Keller (2012, p.265) state that "Marketers can apply branding virtually anywhere a consumer has a choice [...] a place".

Authors (KOTLER and KELLER, 2012; BRAUN, 2011; STACHOW and HART, 2010; ASHWORTH and KAVARATZIS, 2010; MAHESHWARI, 2010; MOILANEN and RAINISTO; 2009; JANSEN, 2008; SZONDI 2007; KAVARATZIZ, 2005; KOTLER and GERTNER, 2004; RAINISTO, 2004) support the idea that nation branding also depends on both communications activities and marketing efforts to advance nation branding strategies in the target market.

However, Simon Anholt (2007) established a reference point by creating the term 'nation brand' when referring to countries focused on their 
reputation and prosperity. Anholt's Index, consultancy and articles are internationally recognized both in the corporate and academic arenas. However, in 2007, Anholt's hexagon approach (Figure 1 below) focuses on his conceptual terminology called Competitive Identity, which centers on national identity and public diplomacy. Nevertheless, according to the author, public diplomacy, government interests and politics integration are, for all intents and purposes, related to the role of "brand management as a component of national policy", corroborated by Dinnie (2009, p.32) and Papadopoulos (2004).

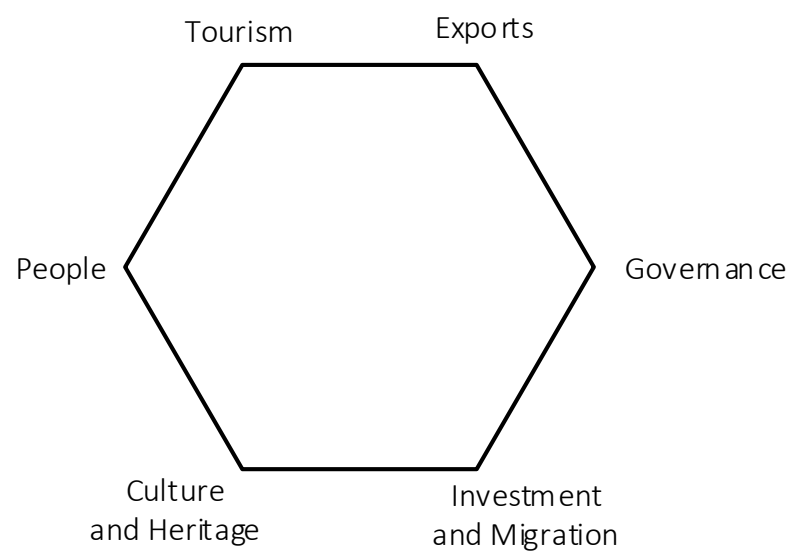

Figure 1: Nation Brand - Anholt's Hexagon Source: Anholt (2007)

Sharing the same principle, Jaffe and Nebenzahl (2001) developed the National Image and Competitive Advantage concept, which considers that although any country conjures up associated mental images, a combination of politics, economy, education, also contributes to the national image. As such, the governments and public authorities operate in conjunction with the private sector when competing internationally. According to Tench and Yeomans (2009, p.650), public diplomacy "is the process by which a government communicates with foreign audiences in an attempt to foster an understanding of their ideas and ideals, institutions and culture, as well as their national goals and current policies".

Along these lines, Dinnie (2009, p.15) suggests the conceptual framework known as Nation as a Brand, defining a nation brand as "the unique, multidimensional blend of elements that provide the nation with culturally grounded differentiation and relevance for all of its target audiences". Detailed examination of the nation brand concept by Dinnie
(2009) incorporated "perceptual attributes and target markets", advocating that brands remain on "consumers' minds rather than being a totally controllable creation of the marketing function" (DINNIE, 2009, p.15).

Although, there are many theory-based and practice-oriented propositions for the nation brand construct, it is still a conceptually unlimited theory for a number of reasons, which will be discussed later in this literature review, considering a country as a place engaged in nation branding strategies. The five main reasons put forward by the author, based on the literature review and academic concerns, are described below.

First, according to many authors, the origin of nation branding is clearly understood, but remains a questionable and controversial subject. This raises questions, since branding a place means a complex and multidimensional entity is more than a product (DINNIE, 2005; 2009; MOILANEN and RAINISTO, 2009; KAVARATZIS, 2010; WARNABY and MEDWAY, 2013). This is because a place exhibits more than merely tangible and intangible features. Successively, the concept of a place in itself is different from the characteristics of a product or service in any market, and its respective attributes as a place brand, primarily when considering a region, city, a province, a state or a country (KOTLER et al., 1993).

Secondly, previous studies have shown that both place or nation brand topics, such as nation identity, nation image and place or nation branding, are found in several academic disciplines. As mentioned by Fetscherin (2010, p.467) "country brand belongs to the public domain; it is complex and includes multiple levels, components, and disciplines". Several academic researchers have studied either nation or place branding, although there are a number of interdisciplinary and multidisciplinary publications in the literature (ASHWORTH and KAVARATZIS, 2010; GO and GOVER, 2011; GERTNER, 2011; BUHMANN and INGENHOFF, 2013; WARNABY and MEDWAY, 2013). For instance, Gertner (2011, p.96) reminds us of the paradigms and obstacles involved in the place branding concept in relation to a number of disciplines, including "a business topic, public diplomacy urban planning and design and political sciences". Additionally, Dinnie (2016) cites: political geography, political philosophy, political science, international relations, cultural anthropology, social psychology, international law, sociology, and history. 
Other authors consider the field a common point of intersection for research in geography, marketing, regional studies, and tourism (HALL, 2008; LUCARELLI and BRORSTRÖM, 2013). There is increasing concern in previous studies on nation image from different scientific perspectives, including business studies, social psychology, political science and communication science (Buhmann and Ingenhoff, 2013, p.2). As observed in the core information shown in Figure 2, in this study nation branding is reflected based on the subtle link between marketing and communications sciences and international business science resources. Accordingly, in support of this research challenge, Tench and Yeomans (2009, p.634) reflect that "the most important and enduring issue communications professionals face is how to link business strategy and communication".

The various disciplines related to place/nation brand and place branding are shown in Figure 2 below.

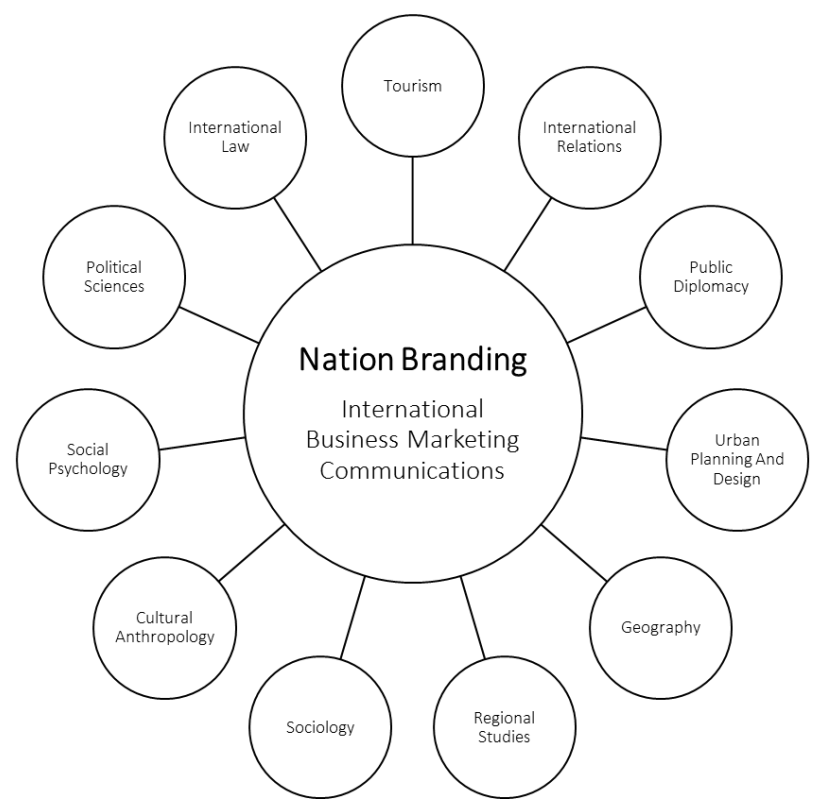

Figure 2: Disciplines related to place (nation) branding Source: Developed by the author based on the literature review

Third, nation brands are fundamentally related not only to nation branding strategies, but also to public policies, which arise from public and private affairs along with political and government interests, playing an important role in the global arena. According to Tench and Yeomans (2009, p.650), "public affairs is a public relations specialism that seeks to influence public policy making via lobbying and/or through the media". Regarding this distinct feature of nation branding, Dinnie (2009, p.13) clearly states that: "it is a highly politicized activity that generates passionately held and frequently conflicting viewpoints and opinions". Contemporary specialists agree that national governments are continuously improving their country branding management abroad (OLINS, 2002; KAVARATZIZ, 2005; BENI, 2006; PIKE, 2007; ANHOLT, 2007; DINNIE, 2008; GO and GOVER, 2011), through branding consultants, public relations advisers, strategic communications experts, theoreticians and practitioners (PIKE, 2008; ARONCZYK, 2013; ZAKAREVIČIUS and LONIKAITÉ, 2013). The practice of branding countries increasingly commands significant political interest and government investment (ANHOLT, 2007; SZONDI 2007; MOILANEN AND RAINISTO, 2009). Hence, "in the effort to respond to the demands of competition and attract the desired target groups, place administrators have recognized a valuable ally in marketing theory and practice" Kavaratziz (2005, p.329), since "competition between places is global" (MOILANEN and RAINISTO, 2009, p.8). Recently, Kotler and Keller (2012, p.636) reported that "Government officials want to strengthen their country's image to help domestic marketers who export, and to attract foreign firms and investors."

The fourth point is the considerable diversity of stakeholders directly involved with the nation brand dimensions, namely citizens, tourists, industries, investors, trade partners, politicians (JANSEN, 2008; KAVARATZIS, 2010; RUZZIER and DE CHERNATONY, 2013), researchers, students, professionals, family members, and athletes, among others. Kim, Shim and Dinnie $(2013$, p.35) point out that "for a nation brand, the number of brand touch points is almost infinite, and far greater than for any product or company brand", indicating the complexity and diversity of stakeholders and targets. Additionally, the nation brand can be perpetuated as a business resonance image, that is, "Therefore, country branding becomes part of a self-perpetuating cycle: as a country promotes its brands, those brands will promote the country" (ZEINALPOUR et al., 2013, p.2).

Fifth, and no less important, however, is the lack of a conventional and wide-ranging theoretical archetype for nation brand modelling, which would be a milestone in theory adapted to this century's reality, even though publications are constantly increasing. Additionally, nation brand models come from various interdisciplinary subjects, confirming it as a multifaceted construct (GERTNER, 2011; GO and GOVER, 2011; ASHWORTH and KAVARATZIS, 2010; 
BUHMANN and INGENHOFF, 2013; DINNIE, 2013, 2016; LUCARELLI and BRORSTRÖM, 2013; WARNABY and MEDWAY, 2013) and once again reinforcing the complex and diverse challenge of building a universal model for different countries around the world.

As previously discussed and presented in Figure 3 above, there are five key challenging descriptions that are the main topic of this theoretical paper. First is the idea that nation branding is a multidimensional construct, even more complex than a product per se. Second, place or nation brand topics such as instance, nation identity, nation image and place or nation branding emerged from several academic disciplines. However, this paper will suggest theories from international business studies and communication science materials. Third, nation brands are fundamental to public policies, including both the public and private sectors as well as political and government interest in the global economy. Fourth, there are several different stakeholders involved in nation branding dimensions. Finally, the paper's fifth point is the lack of a universal theoretical nation brand model.

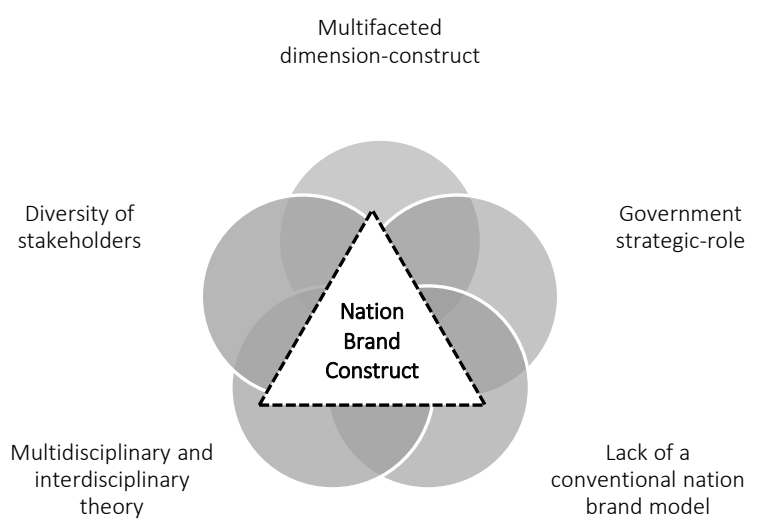

Figure 3: Key complexities of a nation brand construct Source: Developed by the author based on the literature review

To close this first section of the literature review, it is worth mentioning Maheshwari (2010, p.200), who concludes his paper about place branding by stating that one of the concepts that "contribute substantially to promoting the growth prospects of a place" is capability in terms of "revitalized brand image, brand management and stakeholder involvement".

\section{Considerations}

As mentioned in the introduction, there are complex factors involved in nation branding topics, due to the multiple stakeholders and multifaceted dimensions of a nation as a product or service. Dinnie $(2009$, p.13) usefully summarized that nation branding is a threesided area from a research perspective because it is "exciting, complex and controversial". For the author, 'exciting' means it involves little theory within a "huge amount of real world activity"; 'complex' because there are many disciplines involved in addition to "the conventional brand strategy" domain; and 'controversial' for being a "highly politicized activity", causing "passionately conflicting viewpoints and opinions" (DINNIE, 2009, p.13).

Previous research has clearly demonstrated that many countries are facing the country brand challenge in order to strengthen and endorse their brand internationally on the international business setting, regardless of the main objective, theory chosen or strategic approach.

The following interpretations can be drawn from the present study, linked to the five key complexities (Figure 3), which underpin this boundless theory in a complex and challenging bond.

First, in relation to the multifaceted nature and complexity of the nation brand construct, this paper has shown that a number of studies have been carried out on the challenging journey of the nation brand construct, which contributes actively to the global economy. Fundamentally, the concept of branding centered on nations means more than mere products because the "nation brand 'belongs' to everyone and as such, to the nation's entire citizenry" (DINNIE, 2009, p.15; 2016, p.5).

Secondly, as discussed in this reflective paper, there are many disciplines comprising the main topic of this paper - nation branding. Branding along with marketing and communications strategies provide unlimited opportunities for international business to promote and strengthen not only the nation brand, but the country's products and services. By providing authenticity through a dynamic nation branding planning strategy, all countries aim for a positive and solid image worldwide to secure visibility. Comparisons and opinions were out forward on the terminologies concepts from different philosophies and author perspectives. Thus, taken together, these considerations on the evolution of the nation brand construct suggest an association between each 
philosophy, even though they seem completely separate from each other.

Thirdly, it is evident that global competition and market trade mean political interest and the government investment in branding countries occurs continuously.

Fourth, it is clear that stakeholders are the core target, according to different types and niches and applying strategies aimed at reaching any audience with the appropriate content.

Finally, the lack of a standard country brand model further challenges the field. On the other hand, it also motivates researchers toward greater reflection and challenge.

Considering this debate, the stated objectives were achieved because, based on these key complexities, it is accurate to state that any dimension of the nation image has the potential to impact the entire spectrum of the nation branding strategy proposal.

With respect to limitations, as a review paper this is primarily a reflection exercise for readers. Therefore, this paper offers secondary data findings only as genuine results, not primary data. However, the reflections put forward may provide insights for more in-depth investigations and additional topics related to international business.

Indeed, this paper's reflection on nation branding could be applicable to any place, including a city or region of a nation, since its complexity is wellreflected and focused on the dimensions, variables and aspects of the place brand model.

Fundamentally, there is a need for more field research on all aspects of place branding (KAVARATZIS, 2005; GERTNER, 2011). Although many different fields of academic research have conducted country brand studies, few have addressed country image (JAFFE and NEBENZAHL, 2001; WINCHESTER and ROMANIUK, 2003; PHARR, 2005; USUNIER, 2006; FLOREK and INSCH, 2008; NADEAU, HESLOP; O'REILLY and LUK, 2008; PIKE, 2008; ROTH and DIAMANTOPOULOS, 2008; MOILANEN and RAINISTO, 2009; BUHMANN and INGENHOFF, 2013; STREHLAU, SOUZA, STREHLAU and SILVA, 2014).

Fetscherin (2010, p.476) also remarks, "Further studies should also differentiate between large and small countries, or city-nations and island-nations". Warnaby and Medway (2013, p.349) point out that even though investigations are being highlighted, the literature shows a lack of research on place image, given that "the field has not reached a point where we can say that a robust theory is under construction". There are still many unanswered questions as to how place identity is projected by place marketers and how place image is perceived by the public; as well as the extent to which a place image could improve after exploring marketing and communications channels or stakeholder relationships, as suggested by Chan and Marafa (2013), Kavaratziz (2005). Moreover, as discussed by Anholt (2007), these could be used to prompt real changes and improvements in the country.

Furthermore, Strehlau et al. (2014) highlight that "A country's image to consumers has become increasingly important in both corporate expansion and internationalization strategy and processes. When one associates a given brand name or company with a specific country, the outcome may prove to coin competitive advantages or disadvantages".

In general, this paper suggests further studies, which could guide theory-based and practiceoriented proposals for the construction of nation branding shown in Figure 3, for instance, stakeholderrelated, government involvement, interdisciplinary and multidisciplinary possibilities, and potential nation brand models.

Moreover, as recommendations for future research, this study can contribute to further potential considerations and productive knowledge for future insights and applications in different contexts, cities, regions or countries, including several variables in the international business setting, for example if applied to specific industries and markets. There is substantial room for further progress in conveying interdisciplinary and multidisciplinary research on place-related branding, such as place image formation and psychology, place image and economics, place identity, education and place branding strategies, and sustainability.

Further studies on nation branding themes can be undertaken; for instance, while debating branding a place within the current context of international marketing, diplomatic relations, academic and educational exchange programs and national and global sustainability issues, largely in recognition of the requirement to fulfil trade, investment and tourism objectives (Dinnie, 2016) in the international business setting. 
Despite its conceptual nature, this study offers some insight into the nation brand construct and its pertinent and contemporary role, both scientifically and commercially, in the globalization era and sustainable environment. However, this philosophical paper makes several noteworthy contributions to global nation brand reflections, such as the international business setting, which will possibly add knowledge to and enrich researchers' publications, government authority actions, business activities, communicator schemes, and global market sectors. Nevertheless, the main reason for advancing with a nation brand is that it provides a strategic tool for the development of the country per se in the international business setting, when successfully managed, applied, and investigated.

\section{References}

- AAKER, D.A. The value of brand equity. Journal of Business Strategy. v. 13, n. 4, p. 27-32, 1992. DOI: http://dx.doi.org/10.1108/eb039503

- $\quad$ ANHOLT, S. The nation as a brand. Across the Board, v. 37, n. 10, p. 22-27, 2000.

- ANHOLT, S. Competitive Identity: The New Brand Management for Nations, Cities and Regions. New York: Palgrave Macmillan, 2007.

- ARONCZYK, M. Branding the Nation: The Global Business Identity. Oxford: Oxford University Press, 2013.

- ASHWORTH, G.J, Marketing of places: What are we doing? In Ave, G. and Corsico, F. (eds), Marketing Urbano International Conference, Edizioni Torino Incontra, Torino, p. 643-649, 1994.

- ASHWORTH, G. J. and KAVARATZIZ, M. Towards Effective Place Brand Management. Northampton: Edward Elgar Publishing, 2010.

- BIgnami, R. A imagem do Brasil no turismo (in Portuguese) 2. ed. São Paulo: Aleph, 2002.

- BENI, M. C. Política e planejamento de turismo no Brasil (in Portuguese) São Paulo: Aleph, 2006.

- BELLINI N., LOFFREDO A. and PASQUINELLI C. (2010), Managing Otherness. The political economy of place images in the case of Tuscany. In ASHWORTH G.J. and KAVARATZIZ, M. (editors), Brand management for cities: The theory and practice of effective place branding. Cheltenham: Edward Elgar.

- BRAND FINANCE. Nation Brands. 2013. Available from: $<$ http://www.brandfinance.com/> [Accessed 10 December 2013].

- BRAUN, E. History matters: The path dependency of place brands. In: Go, Frank M. and
- GOVERS, Robert. International place branding yearbook 2011: managing reputational risk. London: Palgrave Macmillan, p. 39-46, 2011.

- BUhMANN, A. and INGENHOFF, D. Advancing the Country Image Construct from a Public Relations Perspective: The Constitution of the County Image and its Effect on Travel Behavior. In: EUPRERA 2013 CONFERENCE, Barcelona Spain, p. 1-17, 2013. Proceedings...CD-ROM.

- $\quad$ CEVero, R. The Future Brand Country Index: Country Brand Index 2012-13. 2013. Available from: http://www.futurebrand.com/images/uploads/studies /cbi/CBI_2012-Final.pdf [Accessed 10 December 2013].

- CHAN, C. and MARAFA, L.M. A review of place branding methodologies in the new millennium. Place Branding and Public Diplomacy, v. 9, n. 4, p. 236-253, 2013. DOI: 10.1057/pb.2013.17

- DINNIE, K. Conceptualising nation branding: a qualitative inquiry into an under-theorised domain in marketing. [Ph.D. Thesis] Glasgow Caledonian University, United Kindgom, 2005.

- DINNIE, K. Nation Branding: Concepts, Issues, Practice. Oxon: Elsevier, 2009.

- DINNIE, K. Nation Branding: Concepts, Issues, Practice. $2^{\text {nd }}$ edition. Oxon: Elsevier, 2016.

- DINNIE, K. Nation branding. In: Paliwoda, S. (ed.), Exporting, International and Global Marketing Management: Beyond the fundamentals, London, 2013. Available from: <http://hstalks.com.ezproxy.leedsmet.ac.uk/t> [Accessed 8 October 2013].

- FETSCHERIN, M. The determinants and measurement of a country brand: the country brand strength index. International Marketing Review, v. 27, n. 4, p. 466-479, 2010. DOI: $10.1108 / 02651331011058617$

- FLOREK, M. and INSCH, A. The trademark protection of country brands: insights from New Zealand. Journal of Place Management and Development, Bradford, v. 1, n. 3, p. 292-306, 2008.2 DOI: http://dx.doi.org/10.1108/17538330810911271

- GERTNER, D. Unfolding and configuring two decades of research and publications on place marketing and place branding, Place Branding and Public Diplomacy, v. 7, n. 2, p. 91-106, 2011. DOI: 10.1057/pb.2011.7

- GO, F. M. and GOVERS, R. International place branding yearbook 2011: managing reputational risk. Individual chapter's contributors. London: Palgrave Macmillan, 2011.

- HALL, C. M. Servicescapes, Designscapes, Branding, and the Creation of Place-Identity: South of Litchfield, Christchurch, Journal of Travel and Tourism Marketing, v. 25, n. 3, p. 233-250, 2008. DOI:10.1080/10548400802508101

- haRengel, P. and GBAdAMOSI, A. launching a new nation: The unfolding brand of South Sudan, Place 
Branding and Public Diplomacy, v. 10, n. 1, p. 35-54, 2014. DOI::10.1057/pb.2013.12.

- HILDRETH, J. Place Branding: A view at arm's length. Place Branding and Public Diplomacy, v. 6, n. 1, p. 27-35, 2010. DOI: $10.1057 /$ pb.2010.7

- JAFFE, E. D. and NEBENZAHL, I. D. National Image and Competitive Advantage. Copenhagen: Copenhagen Business School Press, 2001.

- JANSEN, S. C. Designer nations: Neo-liberal nation branding - Brand Estonia, Social Identities, v. 14, n. 1, p. 121-142, 2008. DOI: 10.1080/13504630701848721

- KAPFERER, J. O que vai mudar nas marcas? Porto Alegre: Bookman, 2004.

- KAVARATZIZ, M. Place Branding: A Review of Trends and Conceptual Models. The Marketing Review, v. 5, p. 329-342, 2005.

- KAVARATZIZ, M. Place branding: where do we stand? In: Ashworth, G. and Kavaratziz, M. Towards Effective Place Brand Management. Northampton: Edward Elgar Publishing, 2010.

- KIM, Y.K.; SHIM, S.W. and DINNIE, K. The Dimensions of Nation Brand Personality: A Study of Nine Countries. Corporate Reputation Review, v. 16, n. 1, p. 34-47, 2013. DOI: $10.1057 / \mathrm{crr} .2012 .22$

- KOTLER, P. and GERTNER, D. O estratégico marketing de lugares. Dossiê HSM Management. 44, May-June Edition. (2004)

- KOTLER, P. and KELLER, K. L. Administração de Marketing. $12^{\text {nd }}$ ed. São Paulo: Pearson Prentice Hall, 2012.

- KOTLER, P.; HAIDER, D. and REIN, I. Marketing Places: Attracting Investment, Industry, and Tourism to Cities, States, and Nations. New York: The Free Press, 1993.

- $\quad$ LAMM, S. and MOLNE, H. The nation brand of Italian fashion. [Bachelor Degree] Swedish School of Textiles, 2013.

- LINDEMANN, J. The Economy of Brands. New York: Palgrave Macmillan, 2010.

- lucARelli, A. and BRORSTROM, S. Problematising place branding research: A meta-theoretical analysis of the literature. The Marketing Review, v. 13, n. 1, p. 6581, 2013. DOI: 10.1362/146934713X13590250137826

- MAHESHWARI, V. Interpreting place branding and its significance in sustainable development [Ph.D Thesis] University of Liverpool, United Kingdom, 2010.

- MOILANEN, T. and RAISNISTO, S. How to brand nations, cities and destinations: a planning book for place branding. London: Palgrave Macmillan, 2009.

- MORGAN, N.; PRITCHARD, A. and PRIDE, R. Destination branding: creating the unique destination proposition. Oxford: Elsevier, 2010.

- NADEAU, J.; HESLOP, L.; O’REILlY; N. and LUK, P. Destination in a country image context. Annals of Tourism Research, Oxford, v. 35, n. 1, p. 84-106, 2008.
- OLINS, W. Viewpoints. An interview with Wally Olins: how to brand a nation. London, 2002. Available from: $<$ http://wallyolins.com/includes/how_to_brand_a_nat ion.pdf>. [Accessed 6 February 2011]

- StRehlau, E.C., SOUZA, S. StREhlau, D, and Silva. Brazil's Image: Ten Country Similarities and Differences. Internext - Revista Eletrônica de Negócios Internacionais. São Paulo, v. 9, n. 2, p. 59-74, 2014.

- PAPADOPOUlOS, N. Place branding: evolution, meaning and Implications. Place Branding and Public Diplomacy, v. 1, n. 1, p. 36-49, 2004.

- PAPADOPOULOS, N. and HESLOP, L. Country equity and country branding: Problems and prospects. The Journal of Brand Management, v. 4, n. 5, 294-314, 2002.

- PHARR, J.M. Synthesizing country-of-image (COO) research from the last decade: is the concept still salient in an era of global brands? Journal of Marketing, v. 3, n. 4, p. 34-45, 2005

- PIKE, S. D. Destination marketing: an integrated marketing communication approach. Oxford: Elsevier, 2008.

- RAINISTO, S. K. Success factors of place marketing: a study of place marketing practices in Northern Europe and the United States of America. [Ph.D. Thesis] Helsinki University of Technology, Finland, 2004.

- ROJAS-MENDEZ, J. The Nation Brand Molecule, Journal of Product and Brand Management, v. 22, n. 7, p. $462-$ 472, 2013. DOI: 10.1108/JPBM-09-2013-0385

- ROTH, K.P.; DIAMANTOPOULOS, A. advancing the country image construct. Journal of Business Research, v. 62 , p. 726-740, 2008.2 DOI: 10.1016/j.jbusres.2008.05.014

- RUZZIER, M.K.; DE CHERNATONY, L. Developing and applying a place brand identity model: The case of Slovenia, Journal of Business Research, v. 66, p.45-52, 2013. DOI: 10.1016/j.jbusres.2012.05.023

- SEVIN, E. Thinking about place branding: Ethics of concept. Place Branding and Public Diplomacy, v. 7, n. 3 , p. 155-164, 2011. DOI: 10.1057/pb.2011.15

- SETHI, S.P. and ELANGO, B. The influence of "country of origin" on multinational corporation global strategy: A conceptual framework. Journal of International Management, v. 5, n. 4, p. 285-298, 1999.

- $\quad$ SHIMP, T.A. Integrated Marketing Communications in Advertising and Promotion, 7. Ed. Ohio: SouthWestern/Thomson Learning, 2007.

- STACHOW, G. and HART, C. Exploring place image: Formation and measurement, Place Branding and Public Diplomacy, v. 6, n. 2, p. 145-155, 2010. DOI:10.1057/pb.2010.13

- SZONDI, G. The role and challenges of country branding in transition countries: The Central and Eastern European experience, Place Branding and Public Diplomacy, v. 3, n. 1, p. 8-20, 2007. DOI: 10.1057/palgrave.pb.6000044 
- TENCH, R. and YEOMANS, L. Exploring Public Relations. $2^{\text {nd }}$ Edition, Essex: Pearson Education Prentice Hall, 2009.

- USUNIER, J.C. Relevance in business research: the case of country-of-origin research in marketing. European Management Review, v. 3, p. 60-73, 2006. DOI: http://dx.doi.org/10.1057/palgrave.emr.1500049

- WARNABY, G. and MEDWAY, D. What about the 'place' in place marketing? Marketing Theory, v.13, n.3, p.345363, 2013. DOI:10.1177/1470593113492992

- WINCHESTER, M. and ROMANIUK, J. Evaluative and descriptive response to negative attributes. International Journal of Market Research, v.45, n.1, p.21-33, 2003.
- ZAKAREVIČIUS, P. and LIONIKAITE, J. An Initial Framework for Understanding the Concept of Internal Place Branding, v.67, p.143-160, 2013. Available from: $<$ www.ceeol.com> [Accessed 3 December 2013].

- ZEINALPOUR, H.; SHAHBAZI, N. and EZZATIRAD, H. A Review on City and Country Brand Index, Australian Journal of Basic and Applied Sciences, v. 7, n. 7, p. 317324, 2013. DOI: 10.5829/idosi.wasj.2013.27.11.829

- ZENG, G; GO, F. and KOLMER, C. The impact of international TV media coverage of the Beijing Olympics 2008 on China's media image formation: a media content analysis perspective. International Journal of Sports and Sponsorship, July, p.319-336, 2011.

\title{
About the Author
}

- Fabiana Gondim Mariutti is PhD Candidate in Business at Leeds Beckett University - LBU, Leeds, England, UK. E-mail: famariutti@yahoo.com.br

- CAPES Brasil supported this study

\section{Reflexão sobre a missão desafiadora do constructo marca-país na área de negócios internacionais}

\author{
Fabiana Gondim Mariutti
}

Leeds Beckett University - LBU, Leeds, England, UK

DETALHES DO ARTÍGO
Histórico do Artigo:
Recebido em 5 de junho de 2014
Aceito em 19 de março de 2015
Disponível online em:
19 de dezembro de 2015
Sistema de Revisão
"Double Blind Review"
Editor Científico
Felipe Mendes Borini

Palavras-chaves:

Marca-país

Estratégias de marca-país

Negócios Internacionais

\begin{abstract}
RESUMO
A importância de uma marca-país promovida estrategicamente é um dos propósitos fundamentais em negócios internacionais. Cada nação tenta transmitir seus atributos internacionalmente - não apenas seus produtos e serviços, mas também a sua imagem geral. Além disso, pesquisas sobre o construto de marca-país estão sendo realizadas continuamente em institutos governamentais e ambientes acadêmicos e corporativos. As nações precisam se promover estrategicamente se desejam serem percebidas. Baseada nesta premissa, o objetivo desta reflexão teórica é abordar este constructo para delinear o desenvolvimento desta linha de pesquisa e propor um arcabouço teórica para pesquisas futuras. Este artigo também colabora para o compreensão da missão desafiadora do constructo marca-país, cujas estratégias podem ser aplicadas na prática e na teoria da disciplina. Este estudo conceptual complementa o estado-da-arte sobre as complexidades do construto de marca-país através da compreensão das filosofias-chave sobre o tema depois de traçar a sua evolução. A combinação de resultados ofereceu suporte para a elaboração de um quadro conceptual relacionado com as principais complexidades do construto de marca-país, os quais são os seguintes: natureza multifacetada; variedade de muitos grupos de stakeholders; envolvimento do governo; oportunidades interdisciplinares e multidisciplinares e potenciais modelos para marca-país. Assim, o artigo considera que as estratégias dinâmicas e funcionais de branding para uma marca-país proporcionam autenticidade às nações no cenário internacional de negócios e ao fazê-lo - esta missão desafiadora da marca-país beneficia a economia e o comércio internacional; desenvolve as relações diplomáticas e os avanços de pesquisa sobre marketing internacional; fomenta programas de intercâmbios acadêmicos e de ensino; por fim, avança na sustentabilidade nacional e global.
\end{abstract}

(C) 2015 Internext | ESPM. Todos os direitos reservados! 